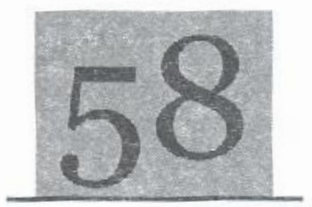

\title{
Comparison of microbiological and proximate analysis of Synodontis nigrita, Chrysichthys nigrodigitatus and Monnymus rume in Olomore Market, Abeokuta, Ogun State, Nigeria
}

Adedeji F. A. / Ibrahim, Z. B.

\section{Abstract}

The study was carried out to compare the microbiolagical and proximate andysis of fresh Synodontis nigrita, Mormyruss rume and Chrysichthys nigrodigitaius sold at Olomore market Aheoluta Ogun State. This fish are alwas availahle at Olomore market and ather fresh fish market around Abcokuta and its environment. The protein, carbonhydrate, moisture, and ash of the fishes was based on the chemical method of tmalysis of the Association of ()fficial Analysis (AOAC:1990). Data for each sp. were subjected io analysis of variance (ANOVA). The Restits show no significant difference in moistufe content of Chrysichthys nigmodigitatus (70.99 - 1.09\%), Mormyrus rume $(67.30 \pm 4.0 .9 \%)$ and Symodontis nigrita $(67.33 \pm 1.99 \%)$. The crude protein content of Chrysichthys nigrodigitutus (12.10 $+0.74 \%)$. Mormyms nume $(1.5 .48+1.63 \%)$ and Synodontis nigrita $(10.73 \pm 0.61 \%)$. For carbohydrate content we have ('hrysichthys nigrodigitatus $(1.15+0.13 \% 9)$. Mormynis rume $(2.09 \perp 0.20 \%)$ and Synodontis nigrita $(2.04 \pm 0.10 \%)$. Fat content of Chrysichthys nigrodigitatus $(7.15+1.29 \%)$ Murmyrus rume $(8.97 \pm 1.9 \%$ ) and Synodontis nigrita $(8.62+0.89 \%)$ and for as 2 conient of (Chrysichthys nigrodigitatus $(6.33 \pm 0.69 \%)$, Mormyrus rume $(4.89 \pm 0.21 \%)$ and Synodontis nigrita $(8.85+0.27 \%)$. For crude protein there was significunt different $(p<0.05)$ same with fat content, ash conteni, and carbohydrate content $(p<0.05)$ unlike moisture content and dry matter content which is $(28.57+1.55 \%),(32.50+4.08 \%)$ and $(32.67+1.99 \%)$ in Chrysichtinys nigrodigitatus, Mormyrus nume and Synodontis nigrita. Resull showed toial bacteria count from 11.9 to $3.8 \times 10^{\circ} \mathrm{cfu} / \mathrm{ml}$ ) from Chrysichthys nigrodigitatus while $(2.8$ to $4.7 \times 10^{6}$ (fuml) was obtained for Synodontis nigrita and $\left(2.6\right.$ to $3.8 \times 10^{6} \mathrm{cfu} / \mathrm{mll}$ ) for Mormyrus rume. The micro-organism isolated were Pseudomonas spp. Escherichia spp. Klebsiella spp.. Staphylococcus spp., Proteeus spp. and Micrococcus spp. On biochemical characterisation the following bacteria was isolated Pseudomonus spp., Escherichia spp. Klebsiella, spp. staphylococcus spp., Protezs spp. and Micrococcus spp.

Keywords: Haematology, sex-reversal, Growth purameters, nutrient utilization, S, melanotheron.

\section{Introduction}

ish and fish product constitute more than $60 \%$ of the total protein intake in adults especially in the rural areas. They are widely accepted on the menu card and form a much-cherished delicacy that cuts across economic, religious and educational barriers (Adeleye 2001).

Fish is a major source of protein and its harvesting, handling, processing and distribution provide livelihood for millions of people. It is a most important animal dictary protein available in the World, and it represents about $14 \%$ of all animal protein on a global basis, (Abolagba and Mella, 2008). Fish is regarded a healthicr meat option due to the high content of long chain poly unsaturated fatty acids (LCPUFA'S), which are associated with improving health and preventing disease of old age (Kabaherda et al., 2009). In Nigeria, fish constitutes $40 \%$ of animal protein intake. Infact, (Ames200I) reported that fish represents a significant proportion of between $30-80 \%$ of total annual protein in the diet of consumers either as fresh or cured fish is a particularly important protein sources in regions where livestock is relatively scarce. In Nigeria, fish is eaten fresh, preserved or processed (smoked) and form a much-cherished delicacy that cut across socio-economic, age, religious and educational barriers (Adebayo-iayo et al., 2008) 
In Nigeria, the fisher folks and sellers of aquatic products neglect the importance of hygiene practice on these products by exposing them to all sorts of pathogens in the markets place where consumers purchase and consume mostly without further processing such as washing, cooking or heating. Microbial contamination could also be due to unhygienic conditions in harvest areas like open poultry manure industrial effluents and sewage disposal into the water bodies in which fish inhabit.

The study was carried out to investigate micro-organism present in fresh selected fish and by so doing identify bacterial loads prevalent in the selected fresh fish obtained and also to know the proximate composition present in selected fresh fish sold in Olomore market, Abeokuta, Ogun State.

\section{Material and Methods}

The samples were collected from Olomore market. A total of 9 samples which comprised 3 different species of (Synodontis nigita, Chrywictithys, nigrodigitatus, Mormyrus rume) were purchased and collected in a sterile aluminum foil and the samples were transported to the microbiology laboratory in awell covered ice cooler for analysis and these samples were labeled G1, L1, I1, G2, L2, I2, G3, L3, I3. A sterile dissecting blade was used to dissect the fish to get the gill, liver and intestine of the fish of different species in a sterile container and analyzed immcdiately. The materials needed for this experiment include glasswares (conical flasks, micropipettes, test tube, petri dishes) and they were washed with detergents.

\section{Results}

Table 1: Proximate composition weight of fresh C. nigrodigitatus, M. rume and S. nigrita from Olomore market Abeokuta, Ogun Siate.

\begin{tabular}{llll}
\hline Composition \% & Chrysichtys nigrodigitatus & Mamyrus rume & Synodantis nigrita \\
\hline Moisture & $70.99 \pm 1.09^{\mathrm{a}}$ & $67.30 \pm 4.08^{\mathrm{a}}$ & $67.33 \pm 1.99^{\mathrm{a}}$ \\
Crude protein & $12.10 \pm 0.74^{\mathrm{b} \mathrm{b}}$ & $15.48 \pm 1.63^{\mathrm{b}}$ & $10.73 \pm 0.61^{\mathrm{a}}$ \\
Crude fat & $7.15 \pm 1.29^{\mathrm{b}}$ & $8.97 \pm 1.90^{\mathrm{b}}$ & $8.62 \pm 0.89^{\mathrm{b}}$ \\
Ash & $6.23 \pm 0.69^{\mathrm{b}}$ & $4.89 \pm 0.21^{\mathrm{a}}$ & $8.85 \pm 0.27^{\mathrm{b}}$ \\
Crude carbohydrate & $1.15 \pm 0.13^{\mathrm{a}}$ & $2.09 \pm 0.20^{\mathrm{b}}$ & $2.04 \pm 0.10^{\mathrm{b}}$ \\
\hline
\end{tabular}

Mean value in the same column with the same superscript are not significantly different.

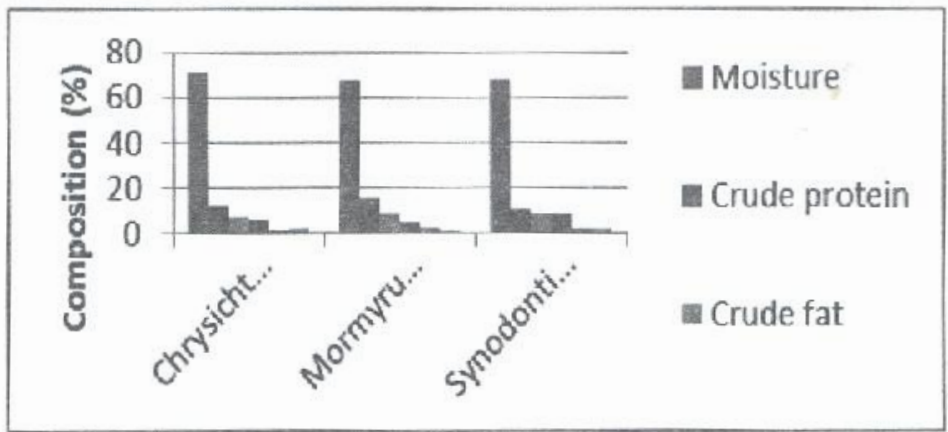

Fig. 1: Proximate composition of fresh fish from Olomore market.

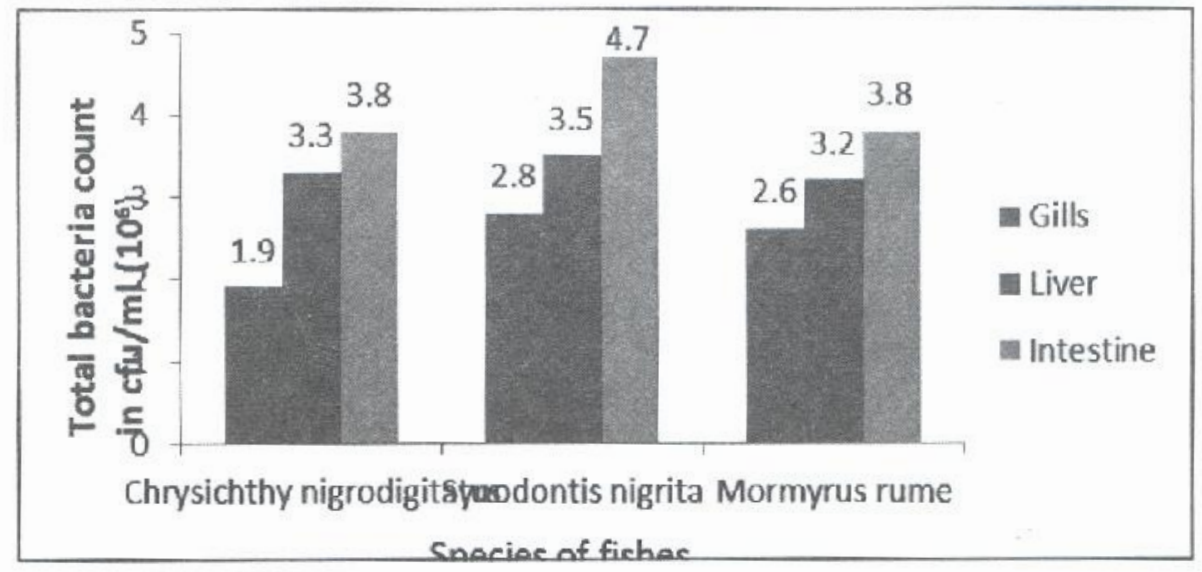

Fig. 2: Total bacteria count in the fresh fish from Olomore market. 
Table 2: Biochemical test of the bacteria isolated from the fish samples-C. nigrodigitatus, M. rume and S. nigrita).

\begin{tabular}{|c|c|c|c|c|c|c|c|c|c|c|c|c|c|c|c|c|c|}
\hline $\begin{array}{l}\bar{g} \\
\text { בั }\end{array}$ & 愛 & 胥 & $\begin{array}{l}\text { 今 } \\
\text { 号 } \\
\text { 근 }\end{array}$ & 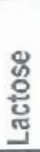 & $\begin{array}{l}\bar{D} \\
\frac{ \pm}{c} \\
\frac{w}{2}\end{array}$ & $\begin{array}{l}\stackrel{8}{0} \\
\frac{0}{10} \\
\frac{\pi}{2}\end{array}$ & $\begin{array}{l}\text { 음 } \\
\text { 믇 }\end{array}$ & 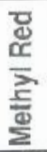 & 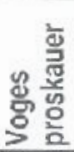 & 递 & ${ }^{\infty}$ & 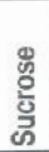 & $\begin{array}{l}\text { g } \\
\text { த }\end{array}$ & 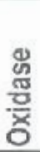 & 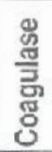 & $\begin{array}{l}\text { 总 } \\
\text { 㸾 } \\
\text { 心 }\end{array}$ & 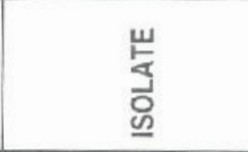 \\
\hline A & - & + & + & - & + & + & - & + & + & + & + & + & + & + & NA & + & Psedomonas spp. \\
\hline B & - & + & + & + & + & + & + & + & - & - & - & NA & - & - & NA & + & Escherichia spp. \\
\hline C & - & - & + & + & + & + & - & - & - & + & - & + & - & - & - & + & Klebsiella spo. \\
\hline D & + & - & + & + & + & + & NA & + & - & + & - & + & + & - & - & + & Staphylococcus spp. \\
\hline$E$ & - & + & + & - & - & - & - & + & - & + & + & + & + & - & + & + & Proteus spp. \\
\hline $\mathrm{F}$ & + & - & + & + & + & + & NA & + & - & NA & NA & + & NA & + & - & + & Micrococcus spp \\
\hline G & - & + & + & + & + & + & - & + & - & + & + & - & - & - & - & + & Citrobacter spp. \\
\hline
\end{tabular}

\section{Discussion}

The proximate composition of analyzed samples of mean value of C. nigrodigitatus, $M$. rume and $S$. nigrita as shown in Table 1. The proximate composition of the fish sample, C. nigrodigitatus, M. rume and S. nigrita ranged from $(67.30 \pm 4.08 \%)$ to $(70.99 \pm 1.09 \%)$. The moisture content was within previously reported range in other fish spp (Osibona et al. 2006). Usually moisture and lipid contents in fish fillets are inversely related and their sum is approximately 80 percent (FAO, 1999). However this value was compared with the US/RDA (1994) of $100 \mathrm{~g}$. There was no significant difference (p>0.05). The value of ash was higher in S. nigrita (8.85 \pm 0.27$)$ than $M$. rume $(4.89 \pm 0.21)$ and $C$. nigrodigitaus $(6.23+0.69)$. For the fat content of $C$. nigrodigitatus, $M$. rume and $S$. nigrita ranged from $(7.15 \pm 1.29)$ to $(8.97 \pm 1.90)$. The higher concentration of the fat content is usually indicative of a high eating and processing quality. The lipid level in the fish tissue is definately due to the influence of food (Onyia et al., 2007). The crude carbohydrate values ranged from $(1.15 \pm 0.13)$ to $(2.09=0.20)$. There was significant difference between them $(\mathrm{P}<0.05)$. The proximatc composition of the fish samples revealed crude protein contents ranges from $(10.73+0.61)$ to $(15.48 \perp 1.63)$. The concentration of the crudc protein content were within the ranges previously reported for C. gariepinus and other fishes (Murray and Burt, 1977; Afolabi et al., 1984; Eyo, 2001; Osibona ct al., 2006; Onyia et al., 2007). For crude fibre content the values ranges $(1.28 \perp 0.15)$ to $(2.44 \pm 0.13)$ and there was significant different between them $(p<0.05)$.

This shows the pathogenic bacteria that are present in the organs of the fresh fish in Olomore market, $\Lambda$ beokuta. The total count (in cfu/ml) of bacteria and fungi present in the organs of fresh fish $C$. nigrodigitains, $M$. rume and $S$. nigrita were analyzed. The total bacteria for C. nigrodigitatus $\left(1.9\right.$ to $\left.3.8 \times 10^{6}\right)$, S. nigrila $\left(2.8\right.$ to $\left.4.7 \times 10^{6}\right)$ and $\mathrm{M}$. rume $(2.6$ to $3.8 \times$ $10^{6}$ ). According to International Commission on Microbiological specification for food (ICMSF, 1986), the maximum recommended bacteria count for good quality product is $5.0 \times 10^{5}(5.710 \mathrm{~g} \mathrm{cfu} / \mathrm{ml})$ and the maximum for marginal acceptable quality products is $1.0 \times 10^{7}(710 \mathrm{~g} \mathrm{cfu} / \mathrm{ml})$. The bacteria load obtained from the fresh fishes C. nigrodigitatus, S. nigrita and $M$. rume obtained from Olomore markets were higher than the recommended value. Therefore, the fishes are not suitable for human consumption. Moreover, the presence of organism could be as a result of handling during fishing and transportation to the market place.

Different types of bacteria were isolated and identified from the organs of the fish samples C. nigrodigitatus, S. nigrita and M. rume (analyzed). Bacteria family include Pseudomonas spp, Stuphylococcus spp dominated the sample followed by Escherichia spp, Klebsiella spp, Micrococcus spp. and Protezs spp which occurred least in the samples. The bacteria group of Staphylococcus spp according to (Robert, 2011) reported that it was one of the most common causes of human discase and they constitute the normal flora of the human skin and mucous membrane without resulting in a diseased condition. This bacteria class may also cause superficial systemic infections such as boils, impetigo and folliculitis while more serious and more common infections could be pneumonia, bacteremia and other infections of the bones and wounds.

Venugopal (2002) had observed that incidence contamination of fish particularly by pathogens may occur prior to harvest, during capture, processing and distribution. Huss et al. (2000) have pointed out that some pathogenic bacteria are naturally present in the aquatic (Clostridium botulinum type E, pathogenic vibro sp., Acromonas) and the general environment (C. botulinum, type A and Listeria monocytogenes) may therefore e found on live or raw fish. Many studies such as the one done Montville et al. (2002) have similarly concluded that, during handling and preparation, bacteria may e transferred from contaminated hands of food workers to food and subsequently to other surfaces. Synder (1998) also found that low infectious doses from organisms such as shigella and the E. coli were linked to hands as a source of contamination. Other studies such as done by Keji et al. (2004) identified equipment as a major source of microbial contamination. With the value reported in this report. It is therefore suggested that consumer should be educated on the adverse effect of using untreated water or polluted water for processing as these could serve as sources of microbial contamination. However, the processors/handlers/sellers should observe strict hygienic measures so that they will not serve as source of chance inoculation of microorganisms.

\section{Conclusion and Recommendation}

The nutrient composition shown that there is higher moisture content and least carbohydrate content in fresh fishes. Chrysichthys nigrodigitatus, Synodontis nigrita and Mormyrus rume gotten from Olomore market in Abeokuta Ogun State. The study has shown that there is high microbial load in fresh fishes gotten from Olomore market $A$ beokuta Ogun State, the fresh fish available in our market contain some micro-organisms and this has effects on the human health. The market environment 
determines the microbiological quality of fresh fish and handling are factor responsible for the contamination of fresh fish in markets. However the following are hereby recommended:

i. Handling, processing and preservation of the fish and other sea foods must be hygienically done.

ii. Consumers of fresh fish and other sea foods should wash and subject these products to further cooking or heating so as to deactivate all heat labile microorganisms present.

The appropriate authority such as federal department of fisheries, ministry of Agriculture and other relevant agency responsible for food safety and hygiene should ensure compliance with public health and hygienic procedure should ensure compliance with public health and hygienic procedure.

\section{REFERENCES}

A.O.A.C. (1990): Official Methods of Analysis of the Association of Analytical Chemists (15th edition) Virginia. 40.

Abdul, W.O. and Omoniyi, T. (2003): An investigation of "Iken" brush park fish aggregating device in Iwopin lagoon, Ogun State Nigeria. Assets 3(3): 168-177.

Abolagba, O.J. and Melle, 0.0 (2008): Chcmical composition and keeping qualities of a scaly fish Tilapia (Oreochromis niloticus) smoked with two energy sources. African J. Gen. Agric, Klobex, 4(2) 113-117.

Adcbayo-Tayo, B.C., Onilude, A.A., Patrick, U.G. (2008): Mycofiora of smoke-dried fishes sold in Uyo, Eastern Nigeria. World J. Agric Sci. 23 ,

Adeleye, O.A. (1992): Conservation needs of needs of fisheries resources and reorientation for sustainable captive and culture practices. Proceedings, 10 th FISON Annual Conference, 230-234.

Afolabi, O.A., Arawomo, O.A. and Oke, O.L. (1984): Quality changes of Nigerian traditional processing of freshwater species: Nutritive and organoleptic changes. I. Food Tech. 19:333-340.

Ames, G.ER. (1991): Postharvest losses of fish in the Tropies. Nanional Resources Institute. 23.

Baker F.J and Beach M. (2000): Viable and total bacteria count. Miles and Mistra method. Microbiology Techniques. 418-423.

Claus, D. (1992): A Standardized gram-staining procedure. Wor. J. Microbial. Biotechnol. 8: 451-452.

Clucas, I.J. and Ward, A.R (1996): Past-Harvest Fisheries Development. A Guide to Handling. Preservation. Processing and Quality. Chatham Maritime, Kent: ME4TB. 665.

Crother C (2005) Catch!: A Fishmonger's Guide to Greatness. Berrett-Koehier Series, Berrett-Koehler Publishers.

Eyo, A.A. (2001): Fish Processing Technology in the Tropics. NIFFR, New Bussa, Niger State. 37-39, 130-138, 153-160, 164

FAO (1995): FAO corporate document respository. "The use of ice on small fishing vessels," Rome, 197pp.

FAO (2005): Joint FAO/WHO activities on risk assessment of microbiological hazards in foods. Preliminary Document. Hazard identification, exposure assessment and hard characterization of vibrio spp in seafood. ftp://ttp.fao.org/es/esn/food/vibrio.pdf.

ICMSF (1998): ICMSF (International Commission on Microbiological Specifications for Foods). Fish and fish produets. microorganisms in foods. Microbial Ecology of Food Commodities. London: Blackie Academic and professional. 130-189.

Kabaherda, M.K.P., Omony and S.M.C. Hiisken. (2009): Post-harvest handling of low value fish products and threats to nutritional Quality. Life. A review of practices in the lake Victoria region. Fisheries and HIV/AIDS in Africa: Investing in sustainable solutions. World Fish Cenier Project Report 1975, pp: 15.

Keji, M. W., Den Aantrekker, E.D. and Ilsi (2004): Europe Risk Analsyis in Microbioogy Task Force. Recontamination as a source of pathogens in processed food. International Journal of Food Microbiology. 91: 1-11.

Kumolu-Johnson C.A, N.F. Aladetohun and P.F. Ndimele. (2009): The effects of smoking on the Nutritional Qualities and Shelf-Life of Clarias garicpinus (BURCHELL 1822). African Journal of Biotechnology, 9(1): 73-76.

Mackean, D. G. (2007): Biology: Characteristics of fish-An introduction. http://ezinearticles.com/?biology-characteristics-of-fish-anintroduction\&id $=481224$.

Murray, J. and Burt, J.R. (1991): The composition of fish, Ministry of Agriculturc. Fisheries and food Tonry, Research Station Advisory Note No. $38.13 \mathrm{pp}$.

Onyia, L.U., Milam, C. and Ese, D. S. (2007): Investigation of heavy metals in four commercial fishes along Upper River Benue, Yola. International Journal of Physical Sciences, $2 / 2$.

Osibona, A.O.. Kusemiju, K. and Akande, G.R. (2006): Proximate composition and fatty acids profile of the African catfish Clarias gariepinus. Journai of Life and Physical Science.

Synder, O.P. (1998): Hand-washing for retail food operational: a review dairy food environment sanitation. 18: 149-162. The International Commission on Microbiolngical Specification for foods (1998). Microorganisms in Foods, Book 6. Microbial Ecology of Food commodities. London: Blackic Academic \& Professional.

Venugopal, V. (2002): Biosensors in fish production and quality control. Biosensors and Bicelectronics. 17: 147-157. 